\title{
KEEFEKTIFAN METODE PEMBELAJARAN KOOPERATIF TIPE TAI DALAM PEMBELAJARAN MEMBACA PEMAHAMAN UNTUK MENEMUKAN GAGASAN UTAMA
}

\author{
Effy Zuliani Hadi dan Haryadi \\ SMPN 2 Gedangsari Gunungkidul \\ effyhadi@yahoo.co.id
}

\begin{abstract}
ABSTRAK
Penelitian ini bertujuan untuk mengetahui: (1) keefektifan metode pembelajaran Kooperatif tipe TAI; (2) perbedaan keefektifan metode Kooperatif tipe TAI dan metode konvensional; (3) metode pembelajaran yang lebih efektif antara metode Kooperatif tipe TAI dan metode konvensional dalam pembelajaran membaca pemahaman untuk menemukan gagasan utama. Penelitian ini merupakan eksperimen semu dengan desain pretest-posttest nonequivalent control group. Populasi penelitian adalah siswa kelas VII SMP Negeri 2 Gedangsari Gunungkidul. Sampel penelitian adalah siswa kelas VIIA dan VIID yang dipilih secara acak. Analisis data menggunakan teknik uji-t dengan taraf signifikansi 0,05 dan untuk menunjukkan keefektifan metode digunakan uji-t nilai gain score. Hasil penelitian menunjukkan bahwa: (1) metode Kooperatif tipe TAI efektif (sig.(p) $=0,00<0,05) ;(2)$ terdapat perbedaan keefektifan yang signifikan antara metode konvensional dengan metode Kooperatif tipe TAI (sig. ( $p)=0,01<0,05$ ); (3) metode Kooperatif tipe TAI lebih efektif dibandingkan metode konvensional dalam pembelajaran membaca pemahaman untuk menemukan gagasan utama tetapi tidak signifikan (sig. $(p)=0,07>0,05)$.
\end{abstract}

Kata Kunci: Team-Assisted Individualization (TAI), membaca pemahaman, gagasan utama

\section{THE EFFECTIVENESS OF COOPERATIVE TEACHING METHOD OF THE TAI TYPE IN TEACHING READING COMPREHENSION TO FIND THE MAIN IDEA}

\begin{abstract}
The study is aimed at finding out: (1) the effectiveness of the Cooperative Method of the TAI type; (2) the differences of the effectiveness of the Cooperative Method of the TAI type and the conventional method; (3) the more effective teaching method between the Cooperative Method of the TAI type and the conventional method in teaching reading comprehension to find the main idea. The research was quasi-experimental with the nonequivalent pretest-posttest control group design. The research population was grade VII students of SMPN 2 Gedangsari Gunungkidul. A sample of VII-A and VII-D students was established randomly. The data analysis was conducted using the $t$-test. The score difference was significant at 0.05 , and the t-test gain score was used to show the effectiveness of the method. The results of the study show that (1) the Cooperative Method of the TAI type is effective $(\operatorname{sig}(p)=0.00<0.05)$; (2) there is a significant difference between the conventional method and the Cooperative Method of the TAI type (sig (p) $0.01<0.05$ ); (3) teaching reading comprehension to find the main idea using the Cooperative method of the TAI type is more effective than that using the conventional method but not significant (sig. $(\mathrm{p})=0,07>0,05)$.
\end{abstract}

Keywords: Team-Assisted Individualization (TAI), reading comprehension, main idea 


\section{PENDAHULUAN}

Keterampilan membaca sebagai salah satu aspek keterampilan berbahasa, sangat penting untuk dikuasai oleh siswa. Penguasaan keterampilan membaca sangat diperlukan sebagai bekal penting yang harus dimiliki agar siswa mampu menghadapi tantangan-tantang an masa depan. Northall (2011) mengatakan bahwa "Strong reading skills are undoubtedly one of the most important skills for any student in higher or further education." Keterampilan membaca yang kuat merupakan keterampilan yang paling penting bagi siswa untuk pendidikan selanjutnya yang lebih tinggi. Namun, kenyataan di lapangan menunjukkan bahwa keterampilan membaca pemahaman masih dianggap sulit bagi sebagian besar siswa SMP. Hal itu dibuktikan dengan hasil survei yang dilakukan oleh Program for International Student Assesment (PISA) pada tahun 2009 (Utomo, 2013). Rata-rata skor prestasi literasi membaca siswa SMP di Indonesia masih di bawah rata-rata internasional. Indonesia yang mem-peroleh skor 402 berada pada peringkat 57 dari 65 negara. Sementara itu, berda-sarkan laporan PIRLS 2011 (Suryaman, 2013: 8) siswa Indonesia mampu menjawab butir soal level sempurna $0,1 \%$, mampu menjawab butir soal level tinggi $4 \%$, mampu menjawab butir soal level sedang $28 \%$, dan mampu menjawab butir soal level lemah $66 \%$. Artinya, siswa Indonesia di level sempurna, tinggi, dan sedang berada di bawah persentase median yang dicapai oleh siswa secara internasional, sementara di level lemah berada di atas median siswa internasional. Dengan kata lain, siswa Indonesia unggul dalam menjawab butir soal level lemah.

Salah satu kendala dalam mengajarkan membaca pemahaman adalah kurang bervariasinya metode, teknik, atau pendekatan yang digunakan guru dalam pembelajaran. Isjoni (2008: 149) mengemukakan bahwa banyak guru yang masih terbiasa dengan cara mengajar monoton. Sebagai akibat dari proses pembelajaran seperti itu, siswa tampak kurang bersemangat mengikuti pelajaran dan seringkali merasa bosan karena mereka tidak dirangsang untuk terlibat secara aktif dengan berbagai variasi yang semestinya dilakukan guru agar tercipta suasana belajar yang kondusif sehingga peserta didik dapat melibatkan diri secara aktif dan kreatif.
Hal sama juga diungkapkan Daryanto \& Rahardjo (2012: 1) yang mengemukakan bahwa "pada kenyataannya di sekolah-sekolah sering kali guru yang aktif sehingga murid tidak diberi kesempatan untuk aktif".

Salah satu pembelajaran yang memberikan kesempatan kepada siswa untuk lebih aktif dan kreatif yaitu pembelajaran Kooperatif (cooperative learning). Metode pembelajaran ini, menurut Daryanto \& Rahardjo (2012: 228) diyakini dapat memberi peluang siswa untuk terlibat dalam diskusi, berpikir kritis, berani dan mau mengambil tanggung jawab untuk pembelajaran mereka sendiri. Pengajar berperan sebagai perancang, fasilitator, dan pembimbing proses pembelajaran. Selanjutnya, Gillies (2007: 1) memaparkan bahwa beberapa penelitian menunjukkan pembelajaran kooperatif sukses digunakan untuk pembelajaran membaca dan menulis siswa sekolah menengah, membaca pemahaman di kelas sains sekolah atas, dan pemecahan masalah pada matematika. Menurut Daryanto \& Rahardjo (2012: 246) pembelajaran Kooperatif tipe TAI mengombinasikan keunggulan pembelajaran kooperatif dan pembelajaran individual. Metode pembelajaran ini akan memotivasi siswa saling membantu anggota kelompoknya sehingga tercipta semangat dalam sistem kompetisi dengan lebih mengutamakan peran individu tanpa mengorbankan aspek kooperatif.

Berdasarkan latar belakang tersebut, masalah dalam penelitian ini adalah sebagai berikut. (1) Apakah metode Pembelajaran Kooperatif tipe TAI efektif pada pembelajaran membaca pemahaman untuk menemukan gagasan utama; (2) Apakah terdapat perbedaan keefektifan pembelajaran membaca pemahaman untuk menemukan gagasan utama antara metode Pembelajaran Kooperatif tipe TAI dan metode pembelajaran konvensional; (3) Metode pembelajaran manakah yang lebih efektif antara metode Pembelajaran Kooperatif tipe TAI dan metode pembelajaran konvensional dalam pembelajaran membaca pemahaman pada siswa kelas VII SMP Negeri 2 Gedangsari Gunungkidul?

Selanjutnya, tujuan penelitian ini adalah sebagai berikut. (1) Mengetahui keefektifan metode Pembelajaran Kooperatif tipe TAI; (2) 
Mengetahui perbedaan keefektifan penggunaan metode Pembelajaran Kooperatif tipe TAI dan metode pembelajaran konvensional; (3) Mengetahui metode pembelajaran yang lebih efektif antara metode Pembelajaran Kooperatif tipe TAI dan metode pembelajaran konvensional dalam pembelajaran membaca pemahaman untuk menemukan gagasan utama.

Hasil penelitian ini diharapkan dapat bermanfaat sebagai berikut. (1) Memberikan pembelajaran membaca pemahaman Bahasa Indonesia yang variatif dan efektif kepada siswa sehingga dapat meningkatkan hasil belajar membaca pemahaman Bahasa Indonesia; (2) Hasil penelitian ini diharapkan dapat memberikan informasi bagi guru mengenai alternatif metode pembelajaran Bahasa Indonesia; (3) Penelitian ini diharapkan juga dapat menjadi bahan pertimbangan guru dalam memilih dan mengembangkan metode pembelajaran Bahasa Indonesia yang akan digunakan. (4) Hasil penelitian ini diharapkan dapat sebagai bahan masukan dalam penyusunan program sekolah terkait dengan pelatihan-pelatihan yang berhubungan dengan metode-metode pembelajaran Bahasa Indonesia yang lebih variatif.

\section{METODE}

Pendekatan penelitian ini adalah penelitian kuantitatif dengan jenis eksperimen semu (quasi experiment) dengan tujuan menguji sebuah perlakuan dengan membandingkan dua perlakuan yang berbeda kepada subjek penelitian. Pada kelompok eksperimen diberi perlakuan dengan menggunakan metode pembelajaran Kooperatif tipe TAI, sedangkan pada kelompok kontrol menggunakan metode pembelajaran konvensional.

Penelitian dilakukan di SMP Negeri 2 Gedangsari Kabupaten Gunungkidul yang berlokasi di Dusun Candi, Desa Tegalrejo, Kecamatan Gedangsari, Kabupaten Gunungkidul, Provinsi Daerah Istimewa Yogyakarta. Adapun waktu penelitian dimulai bulan November 2013 sampai dengan Januari 2014 pada siswa kelas VII semester 2 tahun ajaran 2013/2014.

Populasi penelitian adalah seluruh siswa kelas VII SMP Negeri 2 Gedangsari Gunungkidul tahun pelajaran 2013/2014. Siswa terdiri dari enam kelas dengan jumlah siswa 206 orang.
Selanjutnya, pengambilan sampel dilakukan menggunakan teknik random sampling. Dari enam kelas tersebut diambil dua kelas secara acak dengan cara diundi. Satu kelas sebagai kelompok eksperimen dan satu kelas yang lain sebagai kelompok kontrol.

Langkah-langkah yang dilakukan dalam penelitian ini (Gall \& Borg, 2007: 405) adalah sebagai berikut. (1) menentukan kelompok eksperimen dan kelompok kontrol; (2) memberikan tes awal (pretest); (3) memberikan pembelajaran kepada kelompok eksperimen dan kelompok kontrol; (4) memberikan tes akhir (posttest). Desain yang digunakan dalam penelitian ini adalah pretest-posttest nonequivalent control group design (Wiersma, 1995: 143).

Data, Intrumen, dan Teknik Pengumpulan Data Instrumen yang digunakan dalam penelitian ini yaitu tes pilihan ganda kemampuan membaca pemahaman untuk menemukan gagasan utama. Instrumen tes dalam penelitian ini terdiri atas 25 soal tes. Tes dikerjakan selama 40 menit.

Langkah pertama yang dilakukan dalam penyusunan instrumen tes adalah perencanaan. Selanjutnya, menyusun kisi-kisi tes, memilih bentuk tes, dan menentukan jumlah tes, menulis soal tes, menelaah soal, melakukan uji coba, menganalisis butir soal, memperbaiki tes, merakit tes, melaksanakan tes, dan menafsirkan tes (Mardapi, 2008: 88).

Uji persyaratan analisis dilakukan sebelum uji analisis data, yang terdiri dari uji homogenitas dan uji normalitas. Uji homogenitas dilakukan untuk mengetahui apakah subjek penelitian memiliki varians yang homogen atau tidak. Uji homogenitas varians ini diuji dengan Levene Test, dengan bantuan program SPSS 16 for window. Uji homogenitas dan penarikan kesimpulan didasarkan pada taraf signifikansi dinyatakan homogen jika lebih besar dari 0,05.

Uji Normalitas dilakukan dengan tujuan untuk mengetahui normal atau tidaknya sebaran data penelitian. Pengujian normalitas sebaran data menggunakan metode KolmogorovSmirnov. Perhitungan uji normalitas tersebut dilakukan dengan bantuan komputer program SPSS 16.00 for Windows. Dalam uji normalitas tersebut jika $\mathrm{p}>0,05$, maka hipotesis nol $\left(\mathrm{H}_{0}\right)$ 
yaitu data berasal dari populasi yang berdistribusi normal diterima, dan sebaliknya jika nilai $\mathrm{p}<0,05$, maka hipotesis nol $\left(\mathrm{H}_{0}\right)$ ditolak.

Analisis Deskriptif digunakan untuk menyajikan data yang diperoleh dari hasil pretest dan posttest pada kelompok eksperimen dan kelompok kontrol. Data berupa hasil tes membaca pemahaman untuk menemukan gagasan utama. Data statistik deskriptif tersebut diinterpretasikan dalam bentuk tabel (mean, median, modus, standar deviasi, varians, skor minimum, dan skor maksimum) dan diagram.

\section{Uji Hipotesis}

Pengujian hipotesis yang digunakan dalam penelitian ini adalah uji-t paired samples test dan uji-t independent samples test. Paired samples test digunakan untuk membandingkan nilai dari dua sampel yang berpasangan pada kelompok TAI (hipotesis 1), sedangkan independent samples test digunakan untuk membandingkan nilai dari dua sampel bebas (hipotesis 2). Untuk mengetahui urutan keefektifan antara metode KooperatifTAI dan metode pembelajaran konvensional dilakukan dengan independent samples test nilai Gain Score (Hipotesis 3).

Hipotesis nol $\left(\mathrm{H}_{0}\right)$ ditolak apabila perbedaan nilai signifikan antara kelas kontrol dan kelas eksperimen lebih kecil dari 0,05 (5\%). Hipotesis nol $\left(\mathrm{H}_{0}\right)$ diterima apabila perbedaan nilai signifikan antara kelas kontrol dan kelas eksperimen lebih besar dari 0,05 (5\%).

Analisis data gain dilakukan untuk melihat efek dari metode pembelajaran Kooperatif tipe TAI dalam pembelajaran membaca pemahaman untuk menemukan gagasan utama. Hal ini dilakukan dengan menggunakan rumus gain menurut Meltzer (2002: 183) sebagai berikut.

gain $=\frac{\text { rerata skor post }- \text { rerata skor pre }}{\text { skor maks }- \text { rerata skor pretest }}$

Hasil perhitungan diinterpretasikan dengan menggunakan gain ternormalisasi berdasarkan klasifikasi sebagai berikut.
Tabel 1. Indeks Nilai Gain Ternormalisasi

\begin{tabular}{cc}
\hline Nilai $\mathrm{g}$ & Interpretasi \\
\hline $0,7<\mathrm{g}<1$ & Tinggi \\
$0,3 \leq \mathrm{g} \leq 0,7$ & Sedang \\
$0 \leq \mathrm{g} \leq 0,3$ & Rendah \\
\hline
\end{tabular}

Selanjutnya, dianalisis dengan uji-t independent samples test nilai gain score pretest dan posttest kelompok eksperimen dan kelompok kontrol dilakukan untuk menentukan urutan keefektifan kedua metode tersebut. Kriteria pengujian hipotesis adalah $\mathrm{H}_{0}$ ditolak jika nilai signifikansi $<0,05$ dan $\mathrm{H}_{0}$ diterima jika nilai signifikansi $>0,05$ pada taraf signifikansi $5 \%$.

\section{HASIL DAN PEMBAHASAN}

Deskripsi Data Sebelum Treatment

Variabel penelitian berupa hasil kemampuan awal membaca pemahaman untuk menemukan gagasan utama. Pretest dilakukan untuk mengetahui bahwa kemampuan awal antara kelompok eksperimen dan kelompok kontrol adalah sama. Data yang dianalisis harus dalam keadaan berdistribusi normal dan homogen. Data kemudian dilanjutkan dengan uji-t untuk mengetahui bahwa data tidak memiliki perbedaan kemampuan pada kedua kelompok. Data disajikan pada Tabel 2, 3, dan 4.

Tabel 2. Hasil Uji Normalitas Data Awal

\begin{tabular}{lccc}
\hline Kelompok & $\begin{array}{c}\text { Sig. } \\
\text { Kolmogorov- } \\
\text { Smirnov }\end{array}$ & Sig & Ket. \\
\hline Kontrol & 0,200 & $\mathrm{p}>0,05$ & Normal \\
Eksperimen & 0,200 & $\mathrm{p}>0,05$ & Normal \\
\hline
\end{tabular}

Berdasarkan hasil uji asumsi pada Tabel 2, signifikansi yang diperoleh (p) adalah 0,200, jadi lebih besar dari 0,05. Dengan demikian, dapat disimpulkan bahwa data kemampuan awal pada kelas kontrol dan kelas eksperimen berdistribusi normal. 
Tabel 3. Hasil Uji Homogenitas Data Awal

\begin{tabular}{|c|c|c|}
\hline \multirow[t]{2}{*}{ Variabel } & \multicolumn{2}{|c|}{$\begin{array}{c}\text { Levene test for equality of } \\
\text { variances }\end{array}$} \\
\hline & $\mathrm{F}$ & Sig \\
\hline Skor & 0,470 & 0,496 \\
\hline
\end{tabular}

Hasil uji homogenitas pada Tabel 3 menunjukkan bahwa $\mathrm{p}=0,496$ sehingga dapat disimpulkan bahwa kemampuan membaca pemahaman untuk menemukan gagasan utama adalah homogen karena $p>0.05$. Selanjutnya, untuk mengetahui ada tidaknya perbedaan kemampuan dilakukan dengan uji-t Independent Samples Test. Hasil uji tersebut ditunjukkan pada tabel berikut.

Tabel 4. Uji Independent Samples Test Data Awal

\begin{tabular}{|c|c|c|c|}
\hline & \multicolumn{2}{|c|}{$\begin{array}{c}\text { Levene test for equality } \\
\text { of variances }\end{array}$} & \multirow{2}{*}{$\begin{array}{c}\text { Sig } \\
(2 \text {-tailed) }\end{array}$} \\
\hline & $\mathrm{F}$ & Sig & \\
\hline Pretest & 0,470 & 0,496 & 0,126 \\
\hline
\end{tabular}

Hasil perhitungan independent test Tabel 4 menunjukkan bahwa $p=0,126$ atau lebih besar dari 0,05 sehingga $\mathrm{H}_{0}$ yang menyatakan tidak terdapat perbedaan yang signifikan antara kelompok eksperimen dan kelompok kontrol diterima.

\section{Deskripsi Data Kelas Kontrol}

Data diperoleh dengan memberikan soal yang sama untuk pretest dan posttest masing-masing sebanyak 25 soal dari 50 soal yang valid dalam bentuk pilihan ganda 4 alternatif jawaban. Soal diberikan kepada 33 siswa kelas VII D SMPN 2 Gedangsari Gunungkidul yang menggunakan metode pembelajaran konvensional. Pada saat pretest ada satu siswa yang tidak masuk sehingga hanya diperoleh 32 data pretest. Untuk selanjutnya pembelajaran dan posttest juga hanya menggunakan data 32 siswa tersebut.

Data kemampuan membaca pemahaman untuk menemukan gagasan utama yang menggunakan metode pembelajaran konvensional pada kelas kontrol tersebut dideskripsikan pada Tabel 5.

Tabel 5 menunjukkan bahwa rata-rata skor pretest kelompok kontrol sebesar 64,281 dengan nilai terendah 49,000 dan nilai tertinggi 85,000, sedangkan rata-rata skor posttest kelompok kontrol sebesar 73,187 dengan nilai terendah 58,000 dan nilai tertinggi 91,000. Data tersebut juga memperlihatkan peningkatan rata-rata sebesar 8,906. Jadi, tingkat keefektifan pembelajaran kelompok kontrol mengalami peningkatan sebesar 13,855\%.

\section{Deskripsi Data Kelas Eksperimen}

Data diperoleh dengan memberikan soal pretest dan posttest. Soal diberikan kepada 34 siswa kelas VII A SMPN 2 Gedangsari Gunungkidul yang menggunakan metode pembelajaran Kooperatif tipe TAI.

Data kemampuan membaca pemahaman untuk menemukan gagasan utama yang menggunakan metode pembelajaran Kooperatif tipe TAI pada kelas eksperimen tersebut dideskripsikan pada Tabel 6.

Tabel 5. Deskripsi Skor Pretest dan Posttest Kelas Kontrol

\begin{tabular}{ccccccc}
\hline \multirow{2}{*}{$\begin{array}{c}\text { Kelas } \\
\text { Konvensional }\end{array}$} & \multirow{2}{*}{$\begin{array}{c}\text { Jumlah } \\
\text { Siswa }\end{array}$} & \multicolumn{2}{c}{ Membaca Pemahaman } & \multirow{2}{*}{ Skor Min } & $\begin{array}{c}\text { Skor } \\
\text { Maks }\end{array}$ & Efektivitas \\
\cline { 3 - 4 } & & Rata- rata & Std. Dev. & & & \\
\hline Pretest & 32 & 64,281 & 9,281 & 49,000 & 85,000 & 8,906 \\
Posttest & 32 & 73,187 & 8,098 & 58,000 & 91,000 & $(13,855 \%)$ \\
\hline
\end{tabular}

Tabel 6. Deskripsi Skor Pretest dan Posttest Kelas Eksperimen

\begin{tabular}{|c|c|c|c|c|c|c|}
\hline \multirow{2}{*}{$\begin{array}{c}\text { Kelas } \\
\text { Konvensional }\end{array}$} & \multirow{2}{*}{$\begin{array}{l}\text { Jumlah } \\
\text { Siswa }\end{array}$} & \multicolumn{2}{|c|}{ Membaca Pemahaman } & \multirow{2}{*}{ Skor Min } & \multirow{2}{*}{$\begin{array}{l}\text { Skor } \\
\text { Maks }\end{array}$} & \multirow{2}{*}{$\begin{array}{c}\text { Efektivitas } \\
(\%)\end{array}$} \\
\hline & & Rata- rata & Std. Dev. & & & \\
\hline Pretest & 34 & 67,706 & 8,678 & 52,000 & 85,000 & 12,706 \\
\hline Posttest & 34 & 80,412 & 9,436 & 58,000 & 94,000 & $(18,766 \%)$ \\
\hline
\end{tabular}


Tampak pada Tabel 6 bahwa ratarata skor pretest kelompok eksperimen sebesar 67,706 dengan nilai terendah 52,00 dan nilai tertinggi 85,000 , sedangkan rata-rata skor posttest kelompok eksperimen sebesar 80,412 dengan nilai terendah 58,000 dan nilai tertinggi 94,000. Data tersebut juga memperlihatkan tingkat keefektifan pembelajaran kelompok eksperimen mengalami peningkatan sebesar 18,766\% berdasarkan selisih rata-rata 12,706.

Deskripsi Data Kelas Kontrol dan Kelas Eksperimen

Dari uraian data pretest dan posttest yang diperoleh pada masing-masing kelas, baik kelas kontrol maupun kelas eksperimen, dapat disajikan rangkuman dari keseluruhan data yang diperoleh pada dua kelompok yang menerapkan metode pembelajaran yang berbeda.

\section{Deskripsi Data Pretest}

Data pretest ini memberikan gambaran kemampuan awal siswa pada semua kelompok metode pembelajaran sebelum memperoleh pembelajaran membaca. Data pretest diperoleh dari pemberian tes tertulis dalam bentuk soal pilihan ganda.

Berikut ini deskripsi kemampuan awal kedua kelompok kelas berdasarkan hasil pretest membaca pemahaman dapat dilihat pada Tabel 7.

Berdasarkan data kemampuan awal siswa pada kelompok kontrol dan kelompok eksperimen pada Tabel 7, diketahui perbedaan rata-rata skor siswa antara kelompok kontrol dan kelompok eksperimen selisih sebesar 3,427.
Selain itu, terlihat pula untuk skor pretest kelas kontrol berada di antara 49,000 dan 85,000 dengan standar deviasi 9,281, sedangkan pada kelas eksperimen berada di antara 52,000 dan 85,000 dengan standar deviasi 8,678.

\section{Deskripsi Data Posttest}

Data posttest ini memberikan gambaran kemampuan akhir siswa pada semua kelompok metode pembelajaran setelah memperoleh pembelajaran. Data posttest diperoleh dari pemberian tes tertulis dengan bentuk, jumlah, dan soal yang sama.

Berikut ini deskripsi kemampuan membaca pemahaman untuk menemukan gagasan utama pada kedua kelompok kelas setelah pelaksanaan pembelajaran membaca pemahaman dapat dilihat pada Tabel 8 .

Dari Tabel 8 dapat dijelaskan bahwa kedua hasil posttest yang diperoleh dari masingmasing kelompok yang menerapkan metode pembelajaran yang berbeda tersebut terdapat perbedaan rata-rata skor siswa antara kelompok kontrol dan kelompok eksperimen sebesar 7,225 . Sementara itu, skor posttest kelas kontrol berada di antara 58,000 dan 91,000 dengan standar deviasi 8,098, sedangkan kelas eksperimen berada di antara 58,000 dan 94,000 dengan standar deviasi 9,436.

\section{Hasil Uji Hipotesis}

Analisis data yang digunakan untuk menguji hipotesis adalah analisis statistik inferensial dengan teknik statistk uji-t. Data yang dianalisis adalah data yang diperoleh sebelum maupun setelah pemberian perlakuan. Sebelum

Tabel 7. Deskripsi Data Pretest Kelas Kontrol dan Kelas Eksperimen

\begin{tabular}{|c|c|c|c|c|c|c|}
\hline \multirow{2}{*}{ Kelompok } & \multirow{2}{*}{ Kelas } & \multirow{2}{*}{$\begin{array}{c}\text { Jumlah } \\
\text { Siswa } \\
\end{array}$} & \multicolumn{2}{|c|}{ Pretest } & \multirow{2}{*}{ Skor Min } & \multirow{2}{*}{$\begin{array}{l}\text { Skor } \\
\text { Maks }\end{array}$} \\
\hline & & & Rata- rata & Std. Dev. & & \\
\hline Kontrol & Konvensional & 32 & 64,281 & 9,281 & 49,000 & 85,000 \\
\hline Eksperimen & Kooperatif TAI & 34 & 67,706 & 8,678 & 52,000 & 85,000 \\
\hline
\end{tabular}

Tabel 8. Deskripsi Data Posttest Kelas Kontrol dan Kelas Eksperimen

\begin{tabular}{|c|c|c|c|c|c|c|}
\hline \multirow{2}{*}{ Kelompok } & \multirow{2}{*}{ Kelas } & \multirow{2}{*}{$\begin{array}{c}\text { Jumlah } \\
\text { Siswa }\end{array}$} & \multicolumn{2}{|c|}{ Posttest } & \multirow{2}{*}{ Skor Min } & \multirow{2}{*}{$\begin{array}{c}\text { Skor } \\
\text { Maks }\end{array}$} \\
\hline & & & Rata- rata & Std. Dev. & & \\
\hline Kontrol & Konvensional & 32 & 73,187 & 8,098 & 58,000 & 91,000 \\
\hline Eksperimen & Kooperatif TAI & 34 & 80,412 & 9,436 & 58,000 & 94,000 \\
\hline
\end{tabular}


melakukan analisis statistik dengan uji-t, terlebih dahulu dilakukan uji normalitas dan uji homogenitas.

\section{Data Sebelum Treatment}

Data hasil kemampuan membaca pemahaman untuk mene-mukan gagasan utama yang akan dianalisis harus dalam keadaan berdistribusi normal dan homogen. Data kemudian dilanjutkan dengan uji-t untuk mengetahui bahwa data tidak memiliki perbedaan kemampuan pada kedua kelompok.

Dari hasil uji normalitas kedua kelompok siswa sebelum memperoleh perlakuan, diketahui bahwa nilai signifikansi kedua kelompok kelas lebih besar dari $0,05(\mathrm{p}>\alpha)$ yaitu, 0,200 , maka dapat disimpulkan bahwa pada taraf signifikansi 5\% semua data skor pretest kelompok sampel dari populasi berdis-tribusi normal.

Hasil uji homogenitas data pretest kedua kelompok kelas dapat diketahui bahwa nilai signifikansi yang diperoleh adalah 0,496 atau bernilai lebih dari $0,05(\mathrm{p}>\alpha)$, maka dapat disimpulkan bahwa pada taraf 5\% kedua kelompok data mempunyai varians yang homogen.

Statistik uji-t independent samples test merupakan uji beda mean dua kelompok sampel yang bertujuan untuk mengetahui apakah ada perbedaan mean masing-masing kelompok. Uji-t dapat dilakukan apabila sebelumnya telah terpenuhi asumsi normalitas dan homogenitas.

Berdasarkan hasil analisis uji-t independent test dengan bantuan SPSS 16 for windows diperoleh signifikansi sebesar 0,126 lebih besar dari 0,05 , maka $\mathrm{H}_{0}$ diterima. Hal ini berarti bahwa antara kelompok kontrol dan kelompok eksperimen memiliki kemampuan awal yang sama.

\section{Data Setelah Treatment}

Hasil uji normalitas kedua kelompok menunjukkan bahwa nilai signifikansi kedua kelompok 0,076 dan 0,191 atau lebih dari 0,05 $(\mathrm{p}>\alpha)$, maka dapat disimpulkan bahwa pada taraf signifikansi 5\% kedua kelompok sampel berasal dari populasi yang berdistribusi normal.

Hasil uji homogenitas kedua kelompok menunjukkan bahwa nilai signifikansi yang diperoleh adalah 0,425 dan bernilai lebih dari $0,05(\mathrm{p}>\alpha)$, maka dapat disimpulkan bahwa pada taraf 5\% kedua kelompok data mempunyai varians yang homogen.

\section{Pengujian Hipotesis}

Pengujian asumsi normalitas sebaran dan homogenitas varians telah terpenuhi. Hal ini berarti persyaratan parametrik uji hipotesis menggunakan uji-t dapat dilaksanakan. Hasil hipotesis yang diuji diuraikan sebagai berikut.

\section{Uji Hipotesis Pertama}

Analisis hipotesis pertama menggunakan data pretest dan posttest kelas eksperimen yang menggunakan metode pembelajaran Kooperatif tipe TAI. Analisis hipotesis pertama ini menggunakan uji-t paired samples test. Kriteria pengujian hipotesis uji-t paired samples test mengacu pada taraf signifikansi $0,05(\alpha) . \mathrm{H}_{0}$ diterima jika nilai sig. output $(\mathrm{p})>$ dari $0,05(\alpha)$ dan sebaliknya $\mathrm{H}_{0}$ ditolak jika nilai sig. output (p) $<$ dari 0,05 $(\alpha)$. Hasil dari uji hipotesis yang dilakukan dengan uji-t adalah sebagai berikut.

Tabel 9. Uji Hipotesis I

\begin{tabular}{cccc}
\hline Uji & $\mathbf{t}$ & Sig. & Ket. \\
\hline Hasil & & & $\mathrm{H}_{\mathrm{o}}$ ditolak, \\
pretest- & 12,071 & $0,00<0,05$ & menerima \\
posttest & & & $\mathrm{H}_{\mathrm{a}}$ \\
\hline
\end{tabular}

Berdasarkan uji hipotesis menggunakan uji-t yang terdapat pada Tabel 9, diperoleh nilai signifikansi sebesar 0,000 . Dengan demikian, $\mathrm{H}_{0}$ ditolak dan menerima $\mathrm{H}_{\mathrm{a}}$. Ini berarti pembelajaran dengan metode Kooperatif tipe TAI efektif dalam pembelajaran membaca pemahaman untuk menemukan gagasan utama.

\section{Uji Hipotesis Kedua}

Analisis hipotesis kedua menggunakan data posttest membaca pemahaman kelas eksperimen dan kelas kontrol. Hipotesis kedua menggunakan analisis uji-t independent samples test. Hasil uji-t terlihat pada Tabel 10 berikut.

Tabel 10. Uji Hipotesis II

\begin{tabular}{|c|c|c|c|}
\hline Uji & $\mathbf{t}$ & Sig. & Ket. \\
\hline $\begin{array}{c}\text { Hasil } \\
\text { posttest }\end{array}$ & 3,328 & $0,001<0,05$ & $\begin{array}{c}\mathrm{H}_{\mathrm{o}} \text { ditolak, } \\
\text { menerima } \\
\mathrm{H}_{\mathrm{a}}\end{array}$ \\
\hline
\end{tabular}


Berdasarkan uji hipotesis menggunakan uji-t yang terdapat pada Tabel 10, diperoleh nilai signifikansi 0,001 maka $\mathrm{H}_{0}$ ditolak. Ini berarti bahwa secara signifikan terdapat perbedaan antara pembelajaran membaca pemahaman untuk menemukan gagasan utama menggunakan metode Kooperatif tipe TAI dan metode konvensional.

Kriteria pengujian hipotesis uji-t independent samples test mengacu pada taraf signifikansi $0,05(\alpha) \cdot \mathrm{H}_{0}$ diterima jika nilai sig. output (p) $>$ dari 0,05 $(\alpha)$ dan sebaliknya $\mathrm{H}_{0}$ ditolak jika nilai sig. output $(\mathrm{p})<$ dari $0,05(\alpha)$. Berdasarkan data Tabel 10 dapat dilihat bahwa sig. output (p) berada pada nilai 0,001 yang artinya kurang dari $0,05(\mathrm{p}<\alpha)$, maka $\mathrm{H}_{0}$ ditolak dan $\mathrm{H}_{\mathrm{a}}$ diterima. Dengan demikian, dapat disimpulkan bahwa terdapat perbedaan keefektifan yang signifikan antara penerapan metode pembelajaran Kooperatif tipe TAI dengan metode pembelajaran konvensional

\section{Uji Hipotesis Ketiga}

Analisis hipotesis ketiga menggunakan gain score yang berasal dari data pretest dan posttest membaca pemahaman kelas eksperimen dan kelas kontrol. Analisis gain score dilakukan untuk melihat efek dari metode pembelajaran TAI dalam pembelajaran membaca pemahaman untuk menemukan gagasan utama dengan menggunakan rumus gain menurut Meltzer (2002: 1260) sebagai berikut.

gain $=\frac{\text { rerata posttest }- \text { rerata pretest }}{\text { skor maks }- \text { rerata skor pretest }}$

Berdasarkan tabel data rata-rata pretest dan posttest kelas kontrol diperoleh hasil perhitungan gain sebagai berikut.

gain $=\frac{73,187-64,281}{100-64,281}$

gain $=\frac{8,906}{35,719}$ gain $=0,249$

Kenaikan gain ternormalisasi kelas kontrol sebesar 0,249 dan berkategori rendah. Selanjutnya, berdasarkan tabel rata-rata pretest dan posttest kelas eksperimen diperoleh hasil perhitungan gain score sebagai berikut.

$$
\begin{aligned}
& \text { gain }=\frac{80,412-67,706}{100-67,706} \\
& \text { gain }=\frac{12,706}{32,294} \\
& \text { gain }=0,399
\end{aligned}
$$

Kenaikan gain score ternormalisasi kelas eksperimen sebesar 0,393 dan berdasarkan klasifikasi nilai gain tergolong berkategori sedang.

Selanjutnya, karena data yang diperoleh signifikan berdasarkan analisis hipotesisi kedua maka pengujian hipotesis ketiga untuk mengetahui urutan keefektifan dari kedua metode pembelajaran, analisis dilanjutkan dengan uji gain score. Berikut hasil uji gain score yang dapat dilihat pada Tabel 11.

Berdasarkan hasil pengujian dengan uji-t dalam Tabel 11 dapat diketahui bahwa $\mathrm{P}>0,05(0,072<0,05)$. Dengan kata lain, dapat dikemukakan bahwa metode pembelajaran kooperatif tipe TAI dibandingkan dengan metode pembelajaran konvensional memiliki nilai signifikansi sebesar 0,072 atau lebih besar dari nilai signifikansi yang ditetapkan yaitu 0,05 maka Ho diterima. Dengan demikian, dapat disimpulkan bahwa nilai beda pretest dan posttest antara kelas eksperimen dengan kelas kontrol tidak terdapat perbedaan yang signifikan. Ini berarti pembelajaran membaca pemahaman menggunakan metode pembelajaran Kooperatif TAI tidak lebih efektif dibandingkan metode konvensional.

Berdasarkan Tabel 5 dan Tabel 6 dapat dilihat bahwa peningkatan rata-rata skor kelas

Tabel 11. Uji Hipotesis III

\begin{tabular}{lcccccc}
\hline \multicolumn{1}{c}{ Kelas } & Rerata Nilai & $\mathrm{N}$ & $\mathrm{db}$ & $\mathrm{t}$ & $\mathrm{P}$ & Keterangan \\
\hline Kontrol & 8,9062 & 32 & \multirow{2}{*}{64} & \multirow{2}{*}{1,831} & \multirow{2}{*}{0,072} & Ho diterima, $\mathrm{H}_{\mathrm{a}}$ ditolak \\
Eksperimen & 12,7059 & 34 & & & & \\
\hline
\end{tabular}


kontrol sebesar $13,855 \%$ sedangkan, peningkatan rata-rata skor kelas eksperimen sebesar $18,766 \%$. Jadi, peningkatan kelas eksperimen lebih besar daripada peningkatan rata-rata skor kelas kontrol. Akan tetapi, berdasarkan Tabel 11 dapat diketahui bahwa sig. output (p) berada pada nilai 0,072 yang artinya lebih dari 0,05 (p $>\alpha$ ), maka $\mathrm{H}_{0}$ diterima dan $\mathrm{H}_{\mathrm{a}}$ ditolak. Dengan demikian, dapat disimpulkan bahwa pembelajaran membaca pemahaman untuk menentukan gagasan utama pada kelas eksperimen dengan metode Pembelajaran Kooperatif tipe TAI lebih efektif daripada metode pembelajaran konvensional tetapi tidak signifikan. Dengan kata lain, pembelajaran Kooperatif tipe TAI lebih efektif daripada pembelajaran konvensional pada taraf signifikansi 0,072 .

\section{Pembahasan}

Hasil uji-t paired samples test kelompok eksperimen dengan nilai probabilitas sebesar 0,000 menunjukkan bahwa metode Kooperatif tipe TAI efektif dalam pembelajaran membaca pemahaman untuk menemukan gagasan utama. Selanjutnya, dari hasil uji-t independent samples test kelompok eksperimen dan kelompok kontrol memiliki nilai probabilitas $(\mathrm{p})=0,001$. Jika dibandingkan dengan taraf signifikansi 0,05 maka $p<0,05$ sehingga kesimpulan yang diambil adalah $\mathrm{H}_{\text {a }}$ diterima. Artinya, ada perbedaan yang signifikan antara kelompok eksperimen dan kelompok kontrol. Hal ini membuktikan bahwa pemberian perlakuan pada kelompok eksperimen yaitu pembelajaran dengan menggunakan metode pembelajaran TAI lebih dapat meningkatkan kemampuan membaca pemahaman untuk menemukan gagasan utama siswa kelas VII SMP N 2 Gedangsari.

Perbedaan yang signifikan pada kemampuan akhir membaca pemahaman untuk menemukan gagasan utama disebabkan adanya perbedaan perlakuan pada kedua kelompok. Pada metode pembelajaran Kooperatif tipe TAI proses pembelajaran membaca pemahaman untuk menemukan gagasan utama pada kelas VII A, siswa berpartisipasi aktif melalui diskusi dengan anggota-anggota kelompoknya dalam menyelesaikan tugas yang diberikan. Siswa yang lebih dulu memahami materi yang diberikan membantu menjelaskan kepada teman satu kelompok yang belum memahami materi tersebut. Dari pengamatan selama proses pembelajaran juga terlihat siswa menjadi lebih aktif mempelajari LKS yang diberikan. Selain itu siswa juga diberikan penghargaan berupa bonus nilai dan piagam untuk keberhasilan mereka dalam memberikan kontribusi peningkatan nilai kelompok sehingga menjadi bersemangat dalam belajar dan termotivasi untuk menjadi lebih baik dari sebelumnya.

Sementara itu pada kelas VII D, guru melaksanakan pembelajaran seperti biasa, tidak ada penempatan atau kerjasama dalam kelompok. Diskusi siswa dilakukan sebatas dengan teman sebangku atau teman terdekat mereka. Selain itu tidak ada penghargaan secara khusus yang diberikan kepada siswa maupun kelompok siswa yang mampu menyelesaikan tugas dengan baik. Siswa pun tidak menunjukkan inisiatif untuk lebih aktif bertanya maupun merespon pertanyaan guru. Proses pembelajaran di kelas tampak formal karena siswa cenderung pasif dan aktivitas mereka lebih banyak mendengarkan penjelasan guru dan sesekali mencatat apa yang diterangkan guru.

Perbedaan strategi mengajar dalam metode pembelajaran Kooperatif inilah yang menyebabkan penerapan metode pembelajaran Kooperatif tipe TAI efektif dibandingkan dengan metode pembelajaran konvensional yang tidak melibatkan siswa untuk aktif berdiskusi dengan teman sebaya serta tidak memberikan penghargaan kepada siswa maupun kelompok sehingga siswa tidak termotivasi untuk lebih aktif dan bersemangat dalam belajar.

Hasil uji gain ternormalisasi kelas kontrol dari selisih mean pretest dan posttest kelas kontrol didapat kenaikan gain ternormalisasi sebesar 0,249 dan berkategori rendah, sedangkan hasil uji gain ternormalisasi dari selisih mean pretest dan posttest kelas eksperimen diperoleh kenaikan gain ternormalisasi sebesar 0,393 dan berkategori sedang. Jadi, metode pembelajaran TAI berpengaruh atau memiliki efek sedang terhadap pembelajaran membaca pemahaman untuk menemukan gagasan utama, sedangkan metode pembelajaran konvensional memiliki efek rendah.

Dari uraian di atas, jika membandingkan efektivitas pembelajaran secara signifikan 
ada perbedaan di antara keduanya. Namun, berdasarkan uji independent samples test gain score pretest dan posttest kelas eksperimen dan kelas kontrol, diperoleh hasil sig. 0,072 lebih besar dari taraf signifikansi yang ditetapkan yaitu 0,05. Dari pembahasan tersebut dapat ditarik kesimpulan bahwa penggunaan metode pembelajaran Kooperatif tipe TAI dibandingkan dengan pembelajaran konvensional lebih efektif tetapi tidak signifikan dalam pembelajaran membaca pemahaman untuk menemukan gagasan utama.

\section{SIMPULAN}

Berdasarkan hasil penelitian dan pembahasan dapat ditarik kesimpulan sebagai berikut.(1) Penggunaan metode Kooperatif tipe TAI efektif dalam pembelajaran membaca pemahaman untuk menemukan gagasan utama; (2) Keefektifan penggunaan metode konvensional dan Kooperatif tipe TAI berbeda secara signifikan dalam pembelajaran membaca pemahaman untuk menemukan gagasan utama; (3) Dalam pembelajaran membaca pemahaman untuk menemukan gagasan utama pada siswa kelas VII SMP N 2 Gedangsari Gunungkidul, Metode Kooperatif tipe TAI lebih efektif dibandingkan dengan metode konvensional tetapi tidak signifikan.

\section{DAFTAR PUSTAKA}

Daryanto \& Rahardjo, M. 2012. Model pembelajaran inovatif. Yogyakarta: Gava Media.

Gall, M.D., Gall, J. P., \& Borg, W. R., \&. 2007. Educational research: an introduction. Boston: Pearson Education, Inc.
Gillies, R. M. 2007. Cooperatif learning: Integrating theori and practice. Los Angeles: Sage Publications.

Isjoni \& Ismail, M. A. (Eds.). 2008. Model-model pembelajaran mutakhir. Yogyakarta: Pustaka Pelajar.

Mardapi, Dj. 2008. Teknik penyusunan instrument tes dan nontes. Yogyakarta: Mitra Cendikia Offset.

Meltzer, D. E. 2002. The relationship beetwen mathemathic preparation and conceptual learning gain in physics: a passible "hidden variable" in diagnostic pretest scores. American Journal of Physics 70, 1259-1267.

Northall, N. Februari 2011. Reading outside the EAP classroom. Humanising Languag Teaching. Major Articles. Diambil pada tanggal 8 April 2014 dari http://www. doaj.org.

Suryaman, M. 2013, Mei. Mata pelajaran Bahasa Indonesia dalam kebijakan kurikulum 2013. Makalah disajikan pada Seminar Nasional Peran Guru Bahasa Indonesia untuk Mengoptimalkan Potensi Peserta Didik dalam Kurikulum 2013 di Fakultas Keguruan dan Ilmu Pendidikan UNISSULA Semarang.

Utomo, Y. S. 2013. PISA (Program for International Student Assessment). Diambil pada tanggal 26 April 2013 pukul 10.22 dari http://litbang.kemdikbud.go.id/ index.php/survei-internasional-pisa.

Wiersma, W. 1986. Research methods in education: an introduction. Boston: Allyn and Bacon, Inc. 